\title{
Modified NRCS-CN-TUH methods for distributed rainfall-runoff modeling
}

\author{
Métodos NRCS-CN-HUT modificados para modelagem chuva-vazão distribuída \\ Fagner França da Costa ${ }^{1}$, Adriano Rolim da Paz ${ }^{1}$ (D) and Daniel Gustavo Allasia Piccilli² \\ ${ }^{1}$ Universidade Federal da Paraíba, João Pessoa, PB, Brasil \\ ${ }^{2}$ Universidade Federal de Santa Maria, Santa Maria, RS, Brasil \\ E-mails: fagnerengenheiroambiental@gmail.com (FFC), adrianorpaz@yahoo.com.br (ARP), dga@ufsm.br (DGAP)
}

Received: June 19, 2018 - Revised: January 04, 2019 - Accepted: March 02, 2019

\begin{abstract}
Due to the relative ease of application, the $\mathrm{CN}$ and the Triangular Unit Hydrograph (TUH) methods are commonly used in hydraulic facilities design. This work adapts these methods to incorporate the spatial variability of the physical characteristics of the catchment. The flow travel time (tv) is computed from the DEM and the CN and TUH methods are adapted to produce results on a pixel basis. This methodology is applied to the Cascata I catchment (Porto Alegre - RS), considering two variants: i) TUHout - tv calculated from each pixel up to the catchment outlet; ii) TUHdown - tv computed from one pixel to the immediate downstream. The proposed methodology showed potential to be used for hydrologic modeling of rainfall events in small catchments, as an alternative for providing information useful for urban drainage management, as the characterization of catchment areas with distinct behavior regarding velocities and potential for runoff generation. On the other side, the results showed an underestimation of peak discharges and time to peak. Initial abstraction losses of the $\mathrm{CN}$ method lower than the one originally prescribed provided more realistic results, in agreement to recent studies. There is the need for an improvement of the methodology for the characteristics of the Brazilian catchments besides the simple adaptation of the classical equations of the $\mathrm{CN}$ method to its distributed form.
\end{abstract}

Keywords: Hydrological modeling; Digital terrain model; Geoprocessing.

\section{RESUMO}

Pela facilidade de aplicação, os métodos CN e Hidrograma Unitário Triangular (HUT) são muito usados em projetos de obras hidráulicas. Este trabalho adapta tais métodos para incorporar a variabilidade espacial das características físicas da bacia hidrográfica. O tempo de viagem (tv) do escoamento é computado do MDE e os métodos CN e HUT são adaptados para obter respostas por pixel. Apresenta-se aplicação na bacia hidrográfica Cascata I (Porto Alegre - RS), com duas variantes: i) HUTexu - tv calculados desde cada pixel até o exutório; ii) HUTjus - tv computados de um pixel para o imediato a jusante. A metodologia mostrou potencial para a modelagem hidrológica de eventos chuvosos em pequenas bacias hidrográficas, visando obter subsídios para a gestão da drenagem, tendo em vista a caracterização dos comportamentos diferenciados na bacia quanto às velocidades e capacidades para gerar escoamento. Por outro lado, observou-se subestimativa das vazões de pico e tempos de pico. Taxas de abstração inicial do método CN menores do que a originalmente prescrita foram mais realistas, concordando com estudos recentes. Há necessidade do aprimoramento da metodologia para as características das bacias brasileiras, indo além da simples adaptação das equações clássicas do método CN para forma distribuída.

Palavras-chave: Modelagem hidrológica; Modelo digital do terreno; Geoprocessamento. 


\section{INTRODUCTION}

One of the biggest problems faced by urban drainage engineers and technicians is the lack of hydrological information. In this scarce data situation, where intensity-duration-frequency (IDF) curves and watershed characteristics (relief and land use/land cover) are normally the only information available, the most commonly used models for rainfall-runoff simulation are the Rational method in the micro drainage and the CN (Curve Number) method proposed by the Natural Resource Conservation Service - NRCS or formally SCS (SCS, 1972; USDA, 2007) together with the synthetic triangular unit hydrograph method (TUH) (USDA, 1986, 2007) for macrodrainage.

The relative simplicity of the $\mathrm{CN}$ method makes common its application in watersheds with different characteristics from those where originally the method was proposed (CUNHA et al., 2015). The required data are usually available or easy to obtain, and its mathematical formulation is simple. However, the methodologies received strong critics in the literature about its validity, due to simulating the basin in a lumped form, by fixing the initial abstractions as $20 \%$ of the maximum basin storage (in turn, estimated from the mean value of the $\mathrm{CN}$ ), and the own values of the $\mathrm{CN}$ parameters suggested in the original formulation (e.g., OGDEN et al., 2017; AJMAL; KIM, 2014; CHRISTIANSON; HUTCHINSON; BROWN, 2016; D'ASARO et al., 2014; RUTKOWSKA et al., 2015).

The technology available today would allow using better methodologies, but, firstly, it will continue bumping into the lack of information, especially in countries such as Brazil, and secondly, will find resistance by several professionals in adopting new techniques. Some studies have suggested adaptations such as using alternative values instead of the $20 \%$ of initial abstractions (AJMAL; KIM, 2014; CHRISTIANSON; HUTCHINSON; BROWN, 2016), the calibration of the CN parameter (D'ASARO et al., 2014; RUTKOWSKA et al., 2015), and the spatial variability of the physical characteristics of the watershed (BARTLET'T et al., 2016; GRIMALDI; PETROSELLI; NARDI, 2012; ZHANG et al., 2014).

Specifically, these methods (CN and TUH) were developed without the myriad of remote sensing information and geoprocessing techniques available today. Although these methods may be sufficient for planning and management of urban drainage system, it is important to better understand the distinct behavior in the watershed to develop the best possible solutions and Best Management Practices (BMPs) for each region.

Several methods have been developed to make better use of the currently available information (satellite images, digital elevation models - DEMs, radar, among others) to improve the representation of rainfall-runoff transformation in urban areas. The distributed hydrological models are examples in this sense (CANDELA; BRIGANDI; ARONICA, 2014; FARES et al., 2014; MEJIA; MOGLEN, 2010; SARAVANAN; MANJULA, 2015; SILVEIRA; DESBORDES, 1999), as they try to incorporate the spatial variability of the descriptive parameters of land use and land cover, soil type, vegetation, and topography, as well as spatial rainfall distribution (EMMANUEL et al., 2015; PEREIRA et al., 2016).

In this light, the increasing availability of remote sensing data and ease of use of geoprocessing techniques in Geographic Information Systems (GIS) have encouraged the adoption of distributed hydrological models (JENA et al., 2012; LOBLIGEOIS et al., 2014). Within these techniques, should be highlighted the advance in topographical representation obtained via DEMs and the development of procedures for automated processing of the DEM aiming the extraction of different types of products, such as flow paths, river drainage networks, lengths and slopes of rivers, among others (MAJIDI et al., 2012; PAZ; COLLISCHONN; SILVEIRA, 2006; PAZ; COLLISCHONN, 2007).

In this sense, this paper proposes an alternative methodology to incorporate into the most common models used in urban drainage $(\mathrm{CN}$ and $\mathrm{TUH})$, the spatial heterogeneity representativeness of the physical characteristics of the basin considering the whole simulation process on the pixel level. The proposed methodology estimates the flow travel time based on DEM processing and incorporates the spatial information on rainfall-runoff hydrologic modeling of small watersheds, obtaining thus a distributed modeling per pixel. In Methodology, the proposed formulations are presented in detail, and the study area is characterized, besides the available data. In Results, one can see the comparison between the simulations performed and the events observed, with the main findings described in Conclusions.

\section{METHODOLOGY}

\section{Overview}

The methodology used in this study (Figure 1) is named Hidropixel and consists in adapting the methods NRCS-CN-TUH to operate pixel-by-pixel, but avoiding affecting the characteristics that gave the popularity to these methods, such as its simple applicability and dependence on easily obtainable data.

\section{Description of the study area}

As a case study, the Cascata I catchment was chosen: it occupies an area of approximately $4.93 \mathrm{~km}^{2}$ and is located in the Arroio Dilúvio basin, in the municipality of Porto Alegre

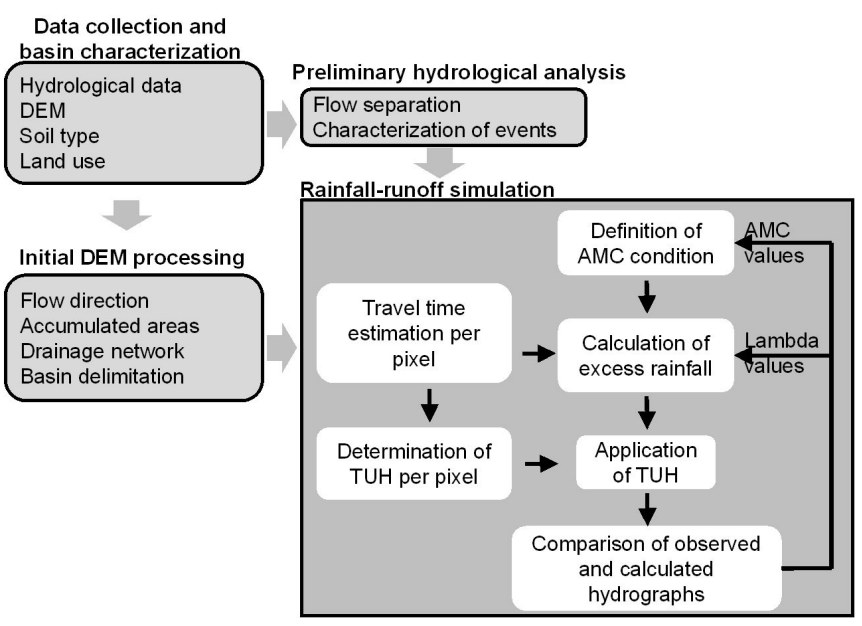

Figure 1. Flow diagram of the main methodological steps. 
(Rio Grande do Sul state, South Brazil; Figure 2). The basin was chosen due to the availability of observed rainfall and runoff data from 1970's and 1980's and reports of problems related to urban floods (SILVEIRA, 2000; BURIN, 2008).

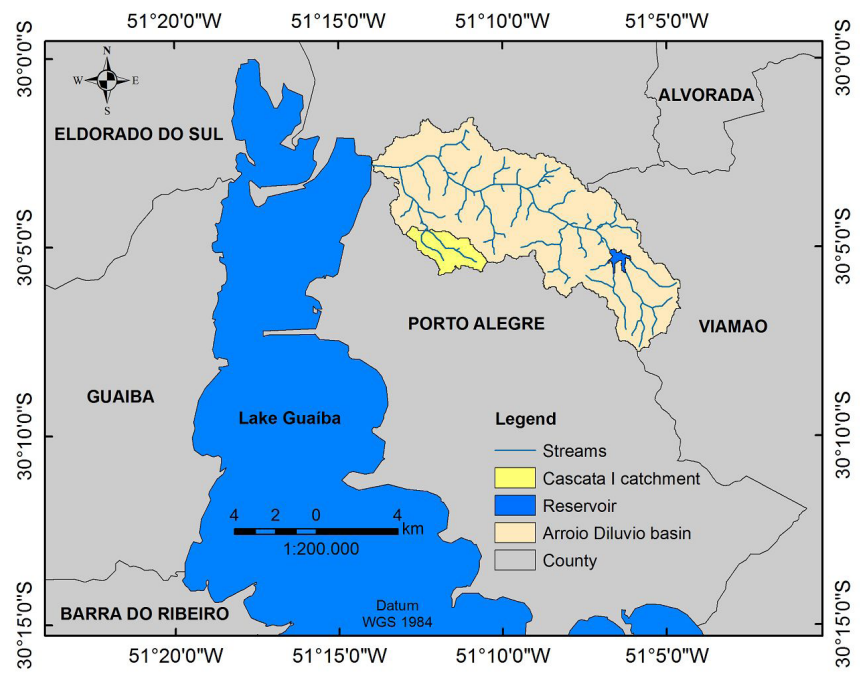

Figure 2. Location of the study area.

\section{Hydrological data}

The Arroio Dilúvio basin was monitored by 11 water level meters and 14 pluviometers between 1978 and 1982 (SILVEIRA, 2000). The equipment had a weekly autonomy, gathering information every 30 minutes. Information from its original paper version was digitized presenting some faulty data due to monitoring problems that were partially fulfilled (SILVEIRA, 2000). More detailed information concerning data fulfilling procedures was not found, however, these data have already been used in other hydrologic modeling studies such as: Silveira and Desbordes (1999), who evaluated a three parameters distributed formulation for rainfall-runoff simulation in this region; Motta Junior and Tucci (1984) and Silveira, Germano and Tucci (1998) that fitted the IPH2 hydrologic model for the basin; and Diaz and Tucci (1987) and Tucci (2003) that derived the TUH parameters.

For this study, the data were obtained through the former "Water and Sewerage Department of Porto Alegre" (in Portuguese, DEP) and from the "Flow Database of Brazilian Urban Basins" (TUCCI; VILLANUEVA; CRUZ, 1998). Within the full record, were selected 24 events of rainfall and runoff (Table 1), presenting a total rainfall ranging from 7.0 to $52.8 \mathrm{~mm}$, and rainfall duration between 1 and $7 \mathrm{~h}$. The average rainfall intensities of these events varied from 1.7 to $21.1 \mathrm{~mm} / \mathrm{h}$ and a maximum of 6.0 to $88.3 \mathrm{~mm} / \mathrm{h}$.

Table 1. Characteristics of the selected events of Cascata I catchment.

\begin{tabular}{|c|c|c|c|c|c|c|c|c|c|c|c|c|}
\hline \multirow[b]{2}{*}{$\begin{array}{c}\text { Event } \\
\text { ID }\end{array}$} & \multirow[b]{2}{*}{ Date } & \multicolumn{6}{|c|}{ Rainfall } & \multicolumn{5}{|c|}{ Flow } \\
\hline & & $\begin{array}{c}P_{\text {total }} \\
(\mathrm{mm})\end{array}$ & $\begin{array}{c}\mathrm{D}_{\text {prec }} \\
\text { (hours) }\end{array}$ & $\begin{array}{c}\mathbf{T}_{\mathrm{c}} \\
\text { (hours) }\end{array}$ & $\begin{array}{c}I_{\text {med }} \\
(\mathrm{mm} / \mathrm{h})\end{array}$ & $\begin{array}{c}I_{\max } \\
(\mathrm{mm} / \mathrm{h})\end{array}$ & $\begin{array}{c}P_{\text {ef }} \\
(\mathrm{mm})\end{array}$ & $\begin{array}{c}Q_{p_{-} \text {sup }} \\
\left(\mathrm{m}^{3} / \mathrm{s}\right)\end{array}$ & $\begin{array}{l}Q_{\mathrm{p}_{\overline{3}} \text { total }} \\
\left(\mathrm{m}^{3} / \mathrm{s}\right)\end{array}$ & $\begin{array}{c}\mathrm{T}_{\mathrm{p}} \\
\text { (hours) }\end{array}$ & $\mathrm{C}_{\text {sup }}$ & $\mathrm{C}_{\text {total }}$ \\
\hline PA070279 & $02 / 07 / 1979$ & 18.66 & 3.00 & 2.50 & 6.22 & 21.44 & 4.95 & 3.15 & 3.34 & 3.50 & 0.27 & 0.33 \\
\hline PA120279 & $02 / 12 / 1979$ & 14.16 & 4.50 & 3.00 & 3.15 & 19.44 & 1.00 & 0.87 & 1.07 & 6.00 & 0.07 & 0.16 \\
\hline PA050479 & $04 / 05 / 1979$ & 7.02 & 2.00 & 3.00 & 3.51 & 8.00 & 1.17 & 0.72 & 0.89 & 3.50 & 0.17 & 0.30 \\
\hline PA170479 & $04 / 17 / 1979$ & 7.02 & 3.50 & 2.50 & 2.01 & 6.00 & 0.49 & 0.27 & 0.37 & 3.50 & 0.07 & 0.18 \\
\hline PA250879 & 08/25/1979 & 12.20 & 1.50 & 3.00 & 8.13 & 18.80 & 1.66 & 1.28 & 1.42 & 2.50 & 0.14 & 0.20 \\
\hline PA240979 & $09 / 24 / 1979$ & 12.60 & 1.00 & 3.00 & 12.60 & 22.00 & 1.11 & 0.96 & 0.99 & 2.00 & 0.09 & 0.10 \\
\hline PA250979 & $09 / 25 / 1979$ & 39.60 & 4.00 & 2.00 & 9.90 & 24.80 & 5.32 & 3.54 & 3.65 & 3.50 & 0.13 & 0.16 \\
\hline PA171179 & $11 / 17 / 1979$ & 28.53 & 5.00 & 3.00 & 5.71 & 18.28 & 4.20 & 2.46 & 2.56 & 5.00 & 0.15 & 0.18 \\
\hline PA061279 & $12 / 06 / 1979$ & 7.54 & 2.00 & 4.50 & 3.77 & 8.28 & 0.54 & 0.45 & 0.49 & 5.00 & 0.07 & 0.10 \\
\hline PA081279 & $12 / 08 / 1979$ & 14.40 & 1.50 & 4.50 & 9.60 & 27.24 & 2.13 & 1.46 & 1.49 & 4.00 & 0.15 & 0.16 \\
\hline PA121279 & $12 / 12 / 1980$ & 52.84 & 2.50 & 1.50 & 21.14 & 88.28 & 7.74 & 7.28 & 7.48 & 2.50 & 0.15 & 0.19 \\
\hline PA090180 & $01 / 09 / 1980$ & 13.03 & 2.50 & 1.50 & 5.21 & 24.00 & 3.24 & 2.97 & 3.13 & 4.00 & 0.25 & 0.34 \\
\hline PA160280 & $02 / 16 / 1980$ & 21.51 & 4.00 & 0.50 & 5.38 & 27.00 & 5.44 & 5.15 & 5.31 & 2.50 & 0.25 & 0.34 \\
\hline PA240280 & $02 / 24 / 1980$ & 13.01 & 3.50 & 1.50 & 3.72 & 18.00 & 2.60 & 2.48 & 2.54 & 2.50 & 0.20 & 0.26 \\
\hline PA110380 & 03/11/1980 & 12.61 & 2.00 & 2.00 & 6.31 & 21.60 & 1.85 & 1.87 & 1.97 & 2.50 & 0.15 & 0.20 \\
\hline PA250380 & $03 / 25 / 1980$ & 17.25 & 1.50 & 2.00 & 11.50 & 34.16 & 2.80 & 2.50 & 2.70 & 2.50 & 0.16 & 0.23 \\
\hline PA280580 & $05 / 28 / 1980$ & 8.37 & 5.00 & 3.00 & 1.67 & 6.08 & 0.53 & 0.27 & 0.46 & 5.50 & 0.06 & 0.24 \\
\hline PA310580 & $05 / 31 / 1980$ & 27.34 & 1.50 & 2.50 & 18.23 & 47.68 & 4.10 & 3.84 & 4.00 & 2.00 & 0.15 & 0.20 \\
\hline PA300680 & $06 / 30 / 1980$ & 11.40 & 2.50 & 1.50 & 4.56 & 11.20 & 0.80 & 0.58 & 0.61 & 2.00 & 0.07 & 0.10 \\
\hline PA080780 & $07 / 08 / 1980$ & 20.81 & 7.00 & 2.00 & 2.97 & 7.20 & 0.87 & 0.38 & 0.40 & 4.50 & 0.04 & 0.06 \\
\hline PA170880 & $08 / 17 / 1980$ & 28.02 & 3.00 & 3.50 & 9.34 & 21.52 & 7.57 & 3.67 & 3.75 & 3.50 & 0.27 & 0.32 \\
\hline PA310880 & $08 / 31 / 1980$ & 17.62 & 4.00 & 1.50 & 4.41 & 10.60 & 2.35 & 1.82 & 1.92 & 3.50 & 0.13 & 0.19 \\
\hline PA221180 & $11 / 22 / 1980$ & 8.09 & 3.00 & 3.00 & 2.70 & 7.84 & 0.81 & 0.47 & 0.84 & 3.50 & 0.10 & 0.38 \\
\hline PA021280 & $12 / 02 / 1980$ & 22.96 & 6.00 & 1.00 & 3.83 & 18.72 & 3.33 & 2.51 & 3.35 & 4.50 & 0.15 & 0.51 \\
\hline
\end{tabular}

$\mathrm{P}_{\text {total }}=$ Total rainfall; $\mathrm{D}_{\text {prec }}=$ Rainfall time; $\mathrm{T}_{\mathrm{c}}=$ Concentration time; $\mathrm{I}_{\text {med }}=$ Average intensity; $\mathrm{I}_{\max }=$ Maximum intensity; $\mathrm{P}_{\mathrm{cf}}=$ Effective rainfall; $\mathrm{Q}_{\mathrm{p} \text { sup }}=$ Peak runoff of surface flow; $\mathrm{Q}_{\mathrm{p} \text { total }}=$ Peak runoff of total flow (surface and base flow); $\mathrm{T}_{\mathrm{p}}=$ time to peak; $\mathrm{C}_{\text {sup }}=$ Surface flow coefficient; and $\mathrm{C}_{\text {total }}=$ Total flow coefficient (surface and base flow). 
As a result of these rainy events, the peak of surface runoff flows varied from 0.3 to $7.3 \mathrm{~m}^{3} / \mathrm{s}$, having occurred 2 to $6 \mathrm{~h}$ after the rain started. The surface flow coefficient ranged from 0.04 to 0.27 .

These same rainfall-runoff events were already used by Silveira, Germano and Tucci (1998) and Tucci, Villanueva and Cruz (2000). These authors mention that, although the full series has been corrected and had its gaps filled, the selected events had no errors or inconsistencies. However, Tucci, Villanueva and Cruz (2000) warned that, in any case, the data should be used sparingly.

\section{Flow separation method}

As the $\mathrm{CN}$ methodology calculates surface runoff, the first step consisted in separating the monitored-flow events between surface and base flow (ARNOLD et al., 1995). For the flow separation was applied the graphical method considering the applicability and wide use. However, the subjectivity in the method is a limitation (WHITE; SLOTO, 1990), leading to uncertainties in the estimates.

\section{Digital Elevation Model: data source and initial processing}

The DEM data was obtained from the Shuttle Radar Topography Mission (SRTM), with approximately 30 meters of spatial resolution. It is a global and free source of topographical data widely used in the literature and, therefore, using these data is interesting to improve the potential use of the methodology proposed in other areas. The DEM was processed to eliminate depressions, obtain the flow directions, accumulated drainage areas, define drainage network and produce catchment delimitation. To remove the depressions and determine the flow direction was employed the Priority First Search (PSF) algorithm as implemented in the software TERRSET and described by Buarque et al. (2009).

The accumulated drainage areas were determined directly from the flow directions, representing for each pixel the upstream contributing area. The watershed was defined by identifying all the pixels draining to the chosen outlet. The drainage network was established based on accumulated areas, assuming the beginning of drainage network in function of a threshold of a minimum accumulated area (FAN et al., 2013). This threshold was chosen by trial and error so that the drainage network was as similar as possible to the network generated for the basin by Hasenack, Weber and Marcuzzo (2008), taken as reference.

\section{Maps of land use and type of soils}

Once the satellite images available between 1978 and 1982 do not provide sufficient accuracy for this study, and the orthophotos used by Alvares and Sanchez (1979) and later by Motta Junior and Tucci (1984) to estimate the basin imperviousness were not found, it was decided to elaborate the land use map based on more recent satellite images. The images were obtained from the Landsat-5 TM (spectral bands: 3, 4 and 5), from August 23, 1987.

The maximum likelihood classification was used for the interpretation of the land use images. This method considers each pixel belonging to only one class, and in this study, in order to simplify, two classes were considered: vegetation and urban area. It has been estimated that $53.55 \%$ of the basin was occupied by vegetation and $4.45 \%$ by urban area (Figure $3 \mathrm{a}$ ).

To verify the applicability of this classification based on more recent images than the monitoring period, the results of the classification were compared with those mentioned by Tucci et al. (1998), Alvares and Sanchez (1979), and Motta Junior and Tucci (1984), which in turn, were based in the orthophotos mentioned. Still, some technicians who worked on the Urban Drainage Plan of Porto Alegre (DEP, 2005a, 2014) were interviewed and, through the software Google Earth, a comparison with the images of 1984 was performed. The comparison and interviews indicated that the image of 1987 would not bring significant uncertainties in the analysis, thus validating its use.

The NRCS-CN hydrologic soil groups (HSG's) map of was elaborated based on the soil map of Porto Alegre (HASENACK; WEBER; MARCUZZO, 2008) that was translated to HSG according to the recommendations of Sartori, Lombardi Neto and Genovez (2005). It has been estimated that $28.6 \%$ of the watershed soil corresponds to type B, and $71.4 \%$ to type D (Figure $3 \mathrm{~b}$ ).
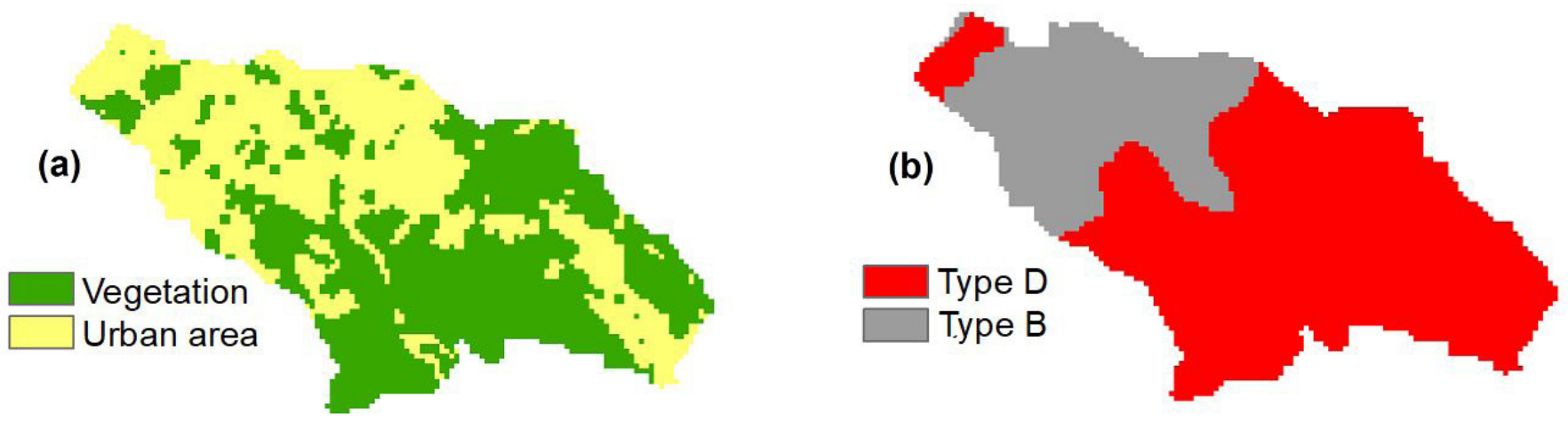

Figure 3. Characterization of land use (a) and (b) soil types of Cascata I catchment. 


\section{Travel time estimation}

For the application of the NRCS-CN-TUH approach (known in USA as TR55 method according to its corresponding technical standard - USDA, 1986), it is necessary to determinate the time of concentration. In this work, the formulation to estimate the time of concentration has been adapted to calculate the flow travel time originated in each pixel until the basin outlet.

The TR55 method uses a methodology that considers the travel time as the sum of the travel time of the undeveloped areas with very slow and shallow overland flow and the travel time along the drainage network (USDA, 1986). This method was chosen because it is widely used in the literature and incorporates the physical characteristics of the basin that can be derived from the DEM (length and slope of the flow paths) and land use map (Manning's coefficient). Such formulation allows differentiating rainfall events on the travel time once the mathematical formulation includes the value of a rainfall depth over a $24 \mathrm{~h}$ duration for the return period specific of the rainfall event.

Equation 1 (USDA, 1986) was employed to estimate the travel time for shallow overland flow. From each pixel considered as not belonging to the drainage network, a flow path is traced downstream until reaching the drainage network. Along this path, the travel time was segmented according to land use.

$T_{s}=\frac{5.474 *\left(\eta_{s} * L_{s}\right)^{0.8}}{P_{24}{ }^{0.5} * S_{s}^{0.4}}$

being: $\eta_{s}=$ Manning's roughness coefficient; $P_{24}=$ rainfall depth for 24 hours $(\mathrm{mm}) ; L_{s}=$ surface flow length $(\mathrm{m}) ; S_{s}=$ slope of the surface flow path (dimensionless); $T_{s}=$ flow travel time on the surface (s).

For each homogeneous land use sub-path, is computed the total travel time of the flow as the sum of each individual pixel to pixel travel time over this sub-path, calculated as Equation 1. For the calculation of the distance $L_{s}$ over the flow path, it is considered an incremental distance equal to the size of the pixel (dx) when the path through the pixel is orthogonal or as $\sqrt{2}$ when the path is diagonal. The slope $S_{s}$ is calculated as the difference of elevation between the pixels of upstream and downstream divided by $L_{s}$. The $\eta_{s}$ is employed corresponding to the upstream pixel to calculate the individual flow travel time.

The $\mathrm{P}_{24}$ is estimated considering the return period of the rainfall event based on the IDF estimated at Posto Redenção station, recommended for the region that covers the study area (Equation 2) (DEP, 2005b). The design of this IDF curve is reported in Silveira, Bemfica and Goldenfum (2000), which was elaborated based on events with Tr equal or superior to 2 years and duration from 10 to $1440 \mathrm{~min}$, with data spanning from 1974 to 1988.

$i=\frac{1,297.9 * T_{r}^{0.171}}{(d+11.6)^{0.85}}$

being: $i=$ rainfall intensity $(\mathrm{mm} / \mathrm{h}) ; d=$ rainfall duration (minutes); $T_{r}=$ return period (years).

It is important to mention that, by means of exploratory analyzes, several authors (SILVEIRA, 1997; SILVEIRA; BEMFICA; GOLDENFUM, 2000; VILLANUEVA; PICCILLI,
2007; FENSTERSEIFER et al., 2013; FAVARETTO, 2014) identified spatial patterns of rainfall associated with urbanization and topography in the region of Porto Alegre. Based on these results, it is possible to observe that, even if the entire basin is less than $5 \mathrm{~km}$ from the Posto Redenção location, the rainfall is slightly lower than the recorded in it, with no possibility of precise quantification. This means that the value of surface travel time can be slightly higher than estimated.

For the calculation of the flow travel time in the drainage network (Tc), the stream was segmented according to geometric characteristics and was employed the Manning equation (Equation 3) to obtain Tc (Equation 4).

$V=\frac{R h^{2 / 3} * S_{c}^{1 / 2}}{\eta_{c}}$

$T_{c}=\frac{L_{c}}{V}$

being: $V=$ the flow velocity in the river channel $(\mathrm{m} / \mathrm{s}) ; R h=$ hydraulic radius (m); $\eta_{c}=$ Manning's roughness coefficient of the channel; $L_{c}=$ channel length $(\mathrm{m}) ; S_{c}=$ channel slope (dimensionless); $T_{c}=$ flow travel time in the network channel (s).

The river network reaches upstream from the stormwater sewer system (conduits) were considered as natural channels, taking into account the dimensions of the conduits and assigning values of Manning's coefficient recommended for natural channels (Table 2). During calibration of the methodology was analyzed the sensitivity of the simulation to changes in the Manning's coefficient of Table 2 that were varied by $\pm 10 \%$ and $\pm 20 \%$.

It is known that during the monitoring period of the hydrological events (1978 to 1982) the upstream channels were not entirely natural and were partly substituted by conduits (ALVARES; SANCHEZ, 1979). However, due to the lack of information of the actual cross sections of reaches, trapezoidal cross sections were adopted (slope ratio of $1 / 2$ ) based on the dimensions (width and height) of the conduits identified in the Urban Drainage Master Plan of Porto Alegre maps (DEP, 2014).

Slopes through the drainage network were obtained by the quotient between the difference in elevation value and the reach length. The elevation values were obtained from the DEM and the lengths measured over the vector drainage network.

Initially, the time of concentration of each observed event was estimated based on monitored rainfall and runoff data, considering it as the time elapsed since the end of the excess rainfall until the end of the surface flow. Then, the Equations 1, 3 and 4 were applied to estimate the time of concentration from

Table 2. Values of the Manning coefficient adopted for different land use (surfaces) and channels.

\begin{tabular}{cc}
\hline $\begin{array}{c}\text { Type of land use (surface) and coating } \\
\text { of the channels }\end{array}$ & $\begin{array}{c}\text { Manning's } \\
\text { coefficient }\end{array}$ \\
\hline Surface - vegetation & 0.155 \\
${ }^{*}$ Surface - urban area & 0.024 \\
${ }^{*}$ Channel - natural & 0.033 \\
${ }^{*}$ Channel - concrete & 0.015 \\
\hline
\end{tabular}

Source: *Canholi (2005). 
the farthest point of the basin until the outlet. The Microsoft Excel solver was used to determine the Manning coefficient of vegetation that would minimize the absolute differences between the concentration-time estimated by the NRCS method (simulated concentration time $\left.-T c_{S i m}\right)$, and the observed concentration time $\left(T c_{o b s}\right)$ for each event.

Finally, it was determined the total flow travel time from each pixel until the basin outlet, as follows: (i) identify the flow travel time downstream a specific pixel until reaching the stormwater sewer system (conduits) (Ts_p); (ii) identify the pixel of the sewer system that received such flow and estimate the flow travel time downstream from the receiving pixel ( $\mathrm{Tc} \_\mathrm{r}$ ) over the channel network until the basin outlet; (iii) the total flow travel time of the pixel $\mathrm{p}$ until the outlet (Tt_p) is given by the sum of Ts_p and Tc_r.

\section{Excess rainfall estimative}

The excess rainfall was estimated by the NRCS-CN (USDA, 1986, 2007) method via Equations 5 to 7 at each pixel.

$h_{e x c}=\frac{(P-\lambda S)^{2}}{(P+(1-\lambda) S)} \quad$ for $P>\lambda S$

$h_{\text {exc }}=0$ for $P \leq \lambda S$

being: $h_{\text {exc }}=$ excess rainfall depth $(\mathrm{mm}) ; P=$ precipitation $(\mathrm{mm})$; $\lambda=$ initial abstraction, which originally is fixed at $20 \% ; S=$ maximum storage (mm).

To determine the value of S, Equation 7 was employed.

$S=\frac{25400}{C N}-254$

being: $C N=$ dimensionless parameter, whose value varies between 0 and 100, where 0 corresponds to an infinite soil infiltration capacity, and 100 corresponds to an impermeable soil.

For each event, historical data of precipitation of Porto Alegre gauging stations (coded 03051011, by HidroWEB -National Water Agency of Brazil (ANA); and coded 83967, the Brazilian National Institute of Meteorology (INMET)) were taken to define the antecedent moisture condition (AMC) and determine the $\mathrm{CN}$, as a function of the total precipitation within 5 days prior to the event. Events with incomplete data in this period were analyzed for the attribution of the AMC, depending on the characteristics of the event itself, mainly the runoff coefficient. The values of CN for AMC II were obtained from Tucci (1993), while the expressions proposed by Mishra et al. (2008) were used to obtain the CN for AMC I and III, from the values of AMC II.

The land use, HSG and AMC were superimposed estimating at each pixel the value of $\mathrm{CN}$ corresponding to each combination

Table 3. Values of $\mathrm{CN}$ for different AMC.

\begin{tabular}{lcccc}
\hline \multirow{2}{*}{ Land use } & \multirow{2}{*}{ Soil type } & \multicolumn{3}{c}{ AMC } \\
\cline { 3 - 5 } & & I & II & III \\
\hline Vegetation & $\mathrm{B}$ & 35 & 55 & 74 \\
& $\mathrm{D}$ & 60 & 77 & 89 \\
Urban area & $\mathrm{B}$ & 52 & 71 & 85 \\
& $\mathrm{D}$ & 71 & 85 & 93 \\
\hline
\end{tabular}

of these variables (Table 3). As the $\mathrm{CN}$ was assigned to each pixel, the initial losses and the maximum storage $S$ were estimated also for each pixel, therefore each pixel will generate a hyetograph of excess rainfall.

\section{Determination and application of a Synthetic Unit Hydrograph}

The hydrograph was estimated by the NRCS-TUH method (USDA, 2007), considering a duration $d$ of 1 minute from an effective unit rainfall. It was the same duration $d$ used to resample observed rainfall. Two variants of the TUH distributed method were developed, assuming a representation were each pixel is treated as a watershed with an area equal to pixel size (dx.dy).

In the first variant (Figure 4a), namely TUHout, the TUH of each pixel is determined as a function of flow travel time from the pixel until the basin outlet $\left(t_{\text {out }}\right)$, by Equations 8 and 10 . The value of $t_{\text {out }}$ is taken as the time of concentration in the formulation of the TUH ( $\mathrm{t}_{\mathrm{d}}=\mathrm{t}_{\text {out }}$ in Equation 8), and the area of the pixel taken as the area of the watershed $(\mathrm{A}=\mathrm{dx} . \mathrm{dy}$ in Equation 10). Therefore, in TUHout, the flow estimated at each pixel corresponds to the pixel response to an excess unit rainfall until reaching the real watershed outlet.

In the second variant of the method (Figure 4b), called TUHdown, the TUH of each pixel is determined as a function of flow travel time within the pixel, i.e. until reaching the pixel immediately downstream $\left(t_{\text {down }}\right)$. The value of $t_{\text {down }}$ is taken as the time of concentration in the formulation of the TUH $\left(t_{d}=t_{\text {down }}\right.$ in Equation 8), and the area of the pixel taken as the area of the watershed $(A=d x . d y$ in Equation 10).
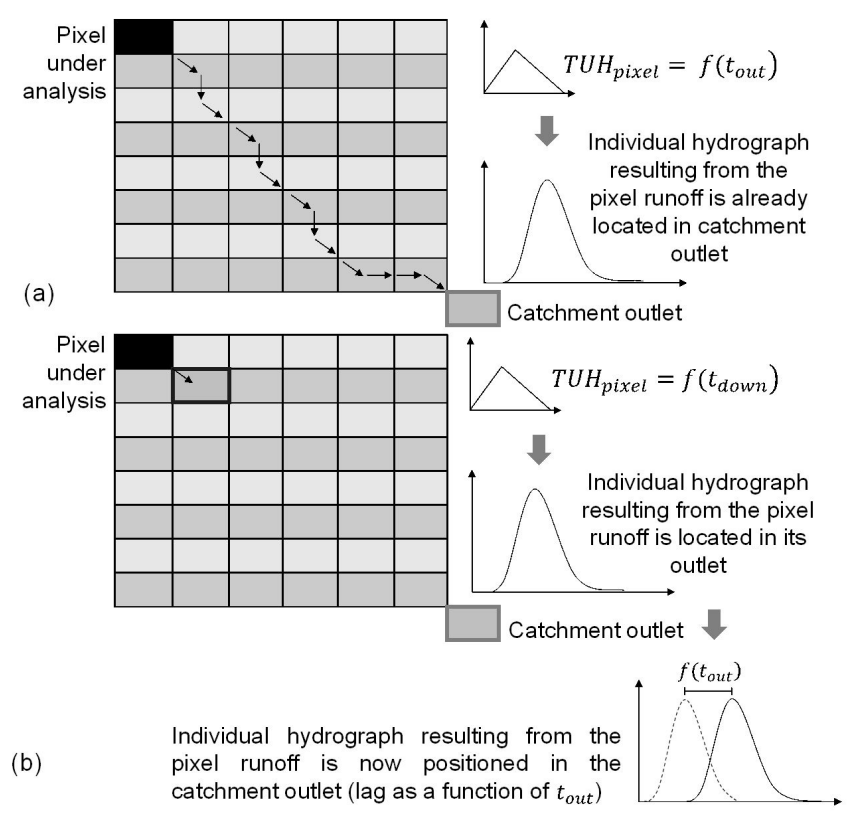

Figure 4. Representative schemes of variants TUHout (a) and TUHdown (b) of the distributed TUH method, being $\mathrm{t}_{\text {out }}$ the flow travel time of the pixel until the basin outlet and $t_{\text {down }}$ the flow travel time of the pixel until the pixel downstream. 
By considering a pixel as a watershed, in TUHdown, the time of concentration is given by the time of the flow until reaching its downstream pixel, which is more sound to the original concept of concentration time. The TUHdown is then the response of each pixel to an excess unit rainfall until reaching the pixel downstream.

$t_{p}=\frac{d}{2}+0.6 * t_{d}$

$t_{b}=2.67 * t_{p}$

$Q_{p}=\frac{0.208 * A}{t_{p}}$

being: $t_{p}=$ time to peak (h); $d=$ duration of precipitation $(\mathrm{h}) ; t_{d}=$ flow travel time $(\mathrm{h}) ; t_{b}=$ base time $(\mathrm{h}) ; Q_{p}=$ peak flow in $\mathrm{m}^{3} \cdot \mathrm{s}^{-1} \cdot \mathrm{mm}^{-1} ; A=$ watershed area in $\mathrm{km}^{2}$.

Whether in the variant TUHout or TUHdown, the basin hydrographs are generated through the convolution of the response of each of the pixels.

For the TUHout method, the hydrologic response of each pixel was already propagated until the watershed outlet, as it was incorporated the value of $t_{\text {out }}$ when solving the pixel individually. The superposition of all these hydrographs resulting from the individual pixels leads to a final hydrograph of the whole watershed.

For the TUHdown, the principles of proportionality and superposition results in hydrographs at each pixel propagated to the pixel downstream. In addition, a lag is applied at each pixel's hydrograph equal to the flow travel time from the pixel until the watershed outlet $\left(t_{\text {out }}\right)$. Then, from the superposition of all these hydrographs with the lag time, the final response of the basin is obtained.

All procedures, as the determination of the flow travel time, the calculation of the excess rainfall, and the acquisition of the resulting unitary hydrograph, were accomplished through computational package named Hidropixel developed by the authors in FORTRAN programming language. Basic input data of the routines are binary raster files (DEM, land use, flow directions, accumulated drainage areas, drainage network, watershed delimitation and CN map) and ASCII files (hydraulic radius, slopes, lengths and roughness coefficients of river reaches, and rainfall event hyetograph). The first computational routine generates flow travel time estimates, both in relation to the basin outlet, as well as in relation to the subsequent downstream pixel. The second routine estimates the excess rain hyetograph per pixel. The results of these routines serve as input for the third, which conceives the TUH per pixel and applies it combined to the excess rain hyetograph. The results are both in georeferenced raster and ASCII files.

\section{Setting the distributed approach}

Initially, the methods NRCS-CN-TUH were applied considering the empirical parameters values unchanged in relation to the original formulation. Then, was calibrated the value for the initial losses parameter ( $\lambda$, Equation 5) for each event in a trial and error process based on suggested values in the literature (e.g., AJMAL; KIM, 2014; CHRISTIANSON; HUTCHINSON; BROWN, 2016; CAZIER; HAWKINS, 1984; BOSZNAY, 1989). Important to note that due to the limited availability of data all the events were calibrated and none was left for the validation steps, as in other studies.

In addition to the visual inspection between observed and calculated hydrographs, it was estimated the relative error (RE) in volume, runoff peak and the time to peak in relation to the observed data. The Nash Sutcliffe coefficient (NS; NASH; SUTCLIFFE, 1970) was also calculated to compare the observed and calculated flows.

\section{RESULTS AND DISCUSSION}

\section{Flow travel time}

The following maps were obtained, initially, through the DEM processing, (i) flow travel time over the surface until reaching the nearest drainage network; (ii) flow travel time over the drainage network until it reaches the basin outlet, and, by combining those information; (iii) total travel time that the flow takes from each pixel of the basin until the outlet. The information (ii) is invariable among the events because it depends only on the hydraulic characteristics and topographic drainage network, and because the same conditions of wet area and perimeter were adopted for all events. The estimate of (ii) was lower than 15 minutes, from any point of the drainage until the basin outlet (Figure 5). The information maps (i) and (iii) vary according to the event, depending on the factor $\mathrm{P}_{24}$ inserted in the estimate of the flow travel time over the shallow surface (eq 1). It is an interesting aspect of this method because is able to capture the distinct flow travel times between events that is expected to occur in reality.

For the event of $12 / 12 / 1979$ as an example, the flow travel time over the surface and the total flow travel time ranged up to a maximum of 5 hours (Figure 5). However, according to the histogram of flow travel times, for $80 \%$ of the basin, the travel time was less than $1.3 \mathrm{~h}$, and for $90 \%$ of the basin less than $2.2 \mathrm{~h}$, approximately. This means that a set of pixels that represent $10 \%$ of the basin showed high travel times, from $2.2 \mathrm{~h}$ to $5 \mathrm{~h}$, depending on the conditions of lower slopes and a land use of higher roughness.

\section{Accumulated excess rainfall}

The estimated excess rainfall for each event varies spatially pixel to pixel due to the variation in $\mathrm{CN}$, as shown for example in Figure 6 for the 03/25/1980 event. Considering the standard formulation of the NRCS-CN method, with an initial abstraction rate of $20 \%$, clearly underestimated excess precipitations were obtained. This distortion has led to the setting of initial abstraction rates lower than $20 \%$ for most events following several authors (AJMAL; KIM, 2014; CHRISTIANSON; HUTCHINSON; BROWN, 2016; CAZIER; HAWKINS, 1984; BOSZNAY, 1989). As the calibration for this parameter was performed from the comparison between observed and calculated hydrographs, distinct but correlated values were obtained for TUHout and TUHdown $\left(\mathrm{R}^{2}=0.96\right.$; Figure 7$)$. The TUHdown approach led to $\lambda$ lowers than the adjusted for TUHout approach. 
In 16 events $(67 \%$ of the total) $\lambda$ was lower than 0.06 and only in 3 events $(12 \%) \lambda$ was larger than $20 \%$. In 11(15) events with the TUHout(TUHdown) approach, $\lambda$ was set to the minimum possible value of 0.01 . These results demonstrated the inadequacy of the original value of $\lambda$ for the simulation of the basin under study with this approach, by inducing too high initial losses, in agreement with the results of Springer et al. (1980), Cazier and Hawkins (1984) and Bosznay (1989), who indicated values in the range of 0 to 0.3 , and Ajmal and $\mathrm{Kim}$ (2014), who recommended $\lambda$ of 0.01 to 0.05 . A recent study developed by Lautharte (2015) for catchments of the Arroio Dilúvio watershed also indicated $\lambda$ close to 0.05 .
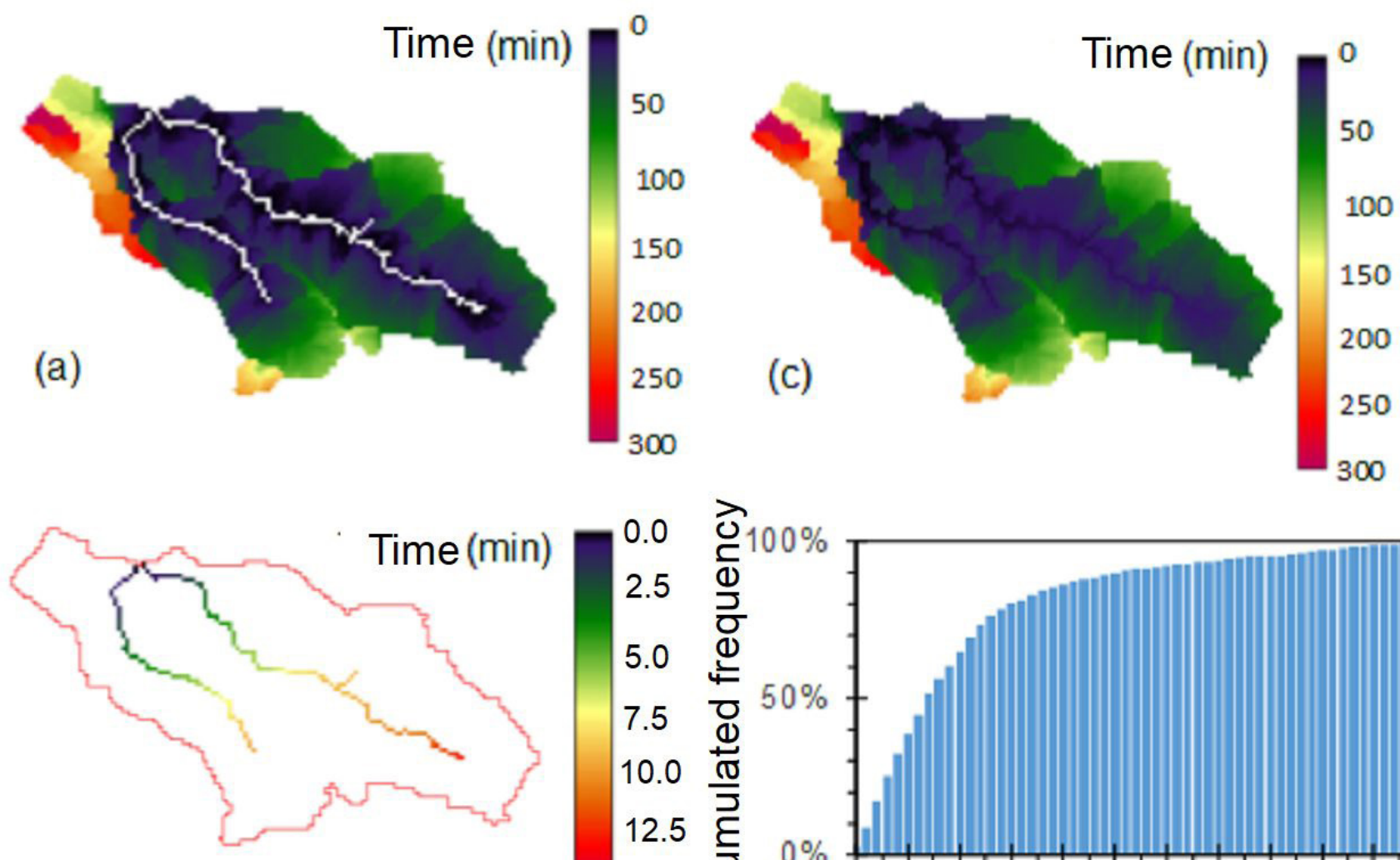

(b)
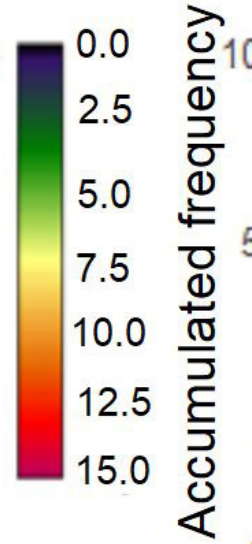

(d)

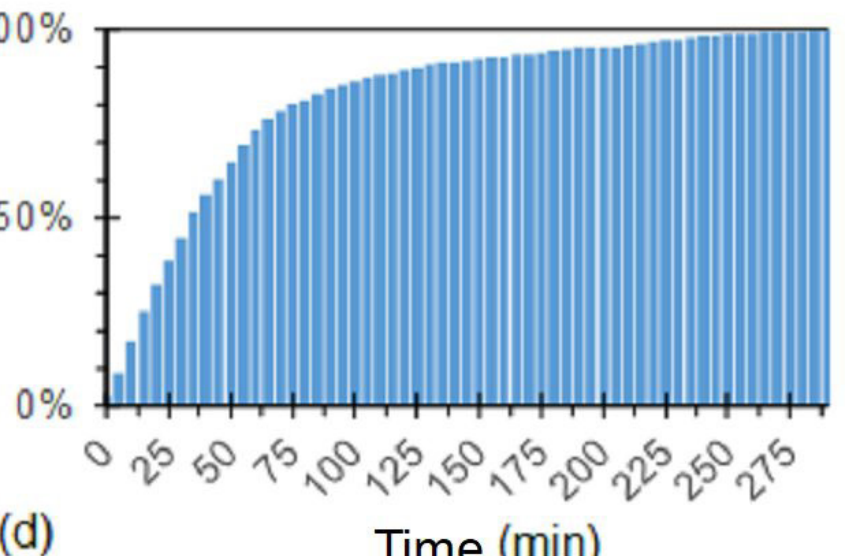

Time (min)

Figure 5. Event of 12/12/1979: maps (a) flow travel time over the surface until reaching the drainage network; (b) flow travel time over the drainage network until the basin outlet; (c) total flow travel time of each pixel until the outlet; and (d) cumulative histogram of flow travel time shown in (c).

(a)

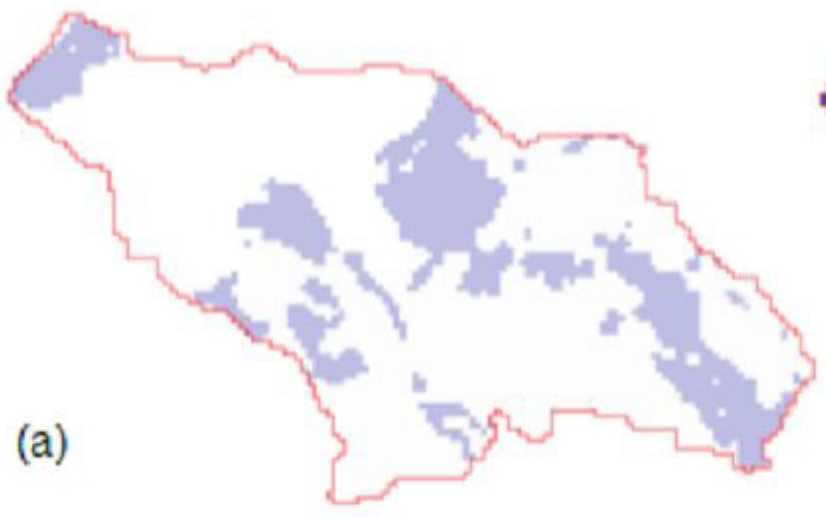

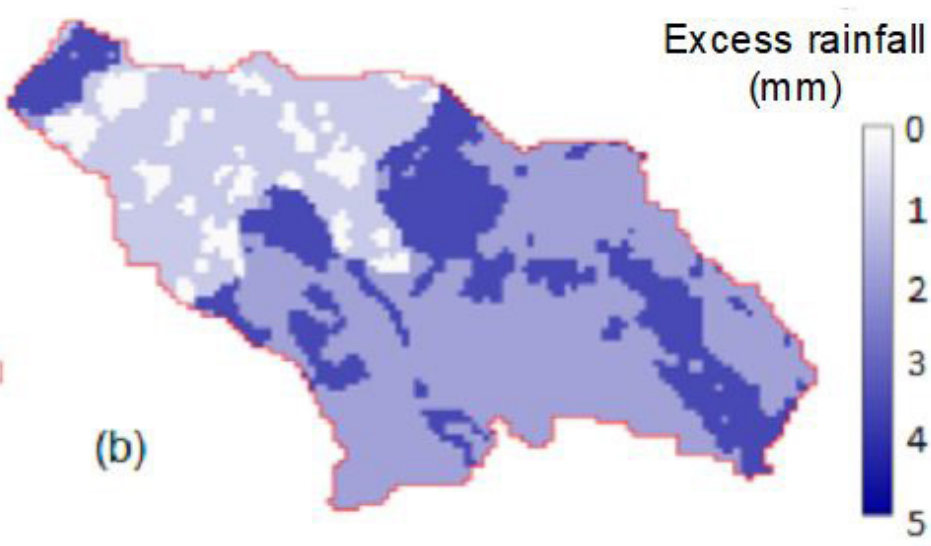

Figure 6. Event of $03 / 25 / 1980$, with the following maps, total excess rainfall considering (a) $\lambda$ of 0.2 (standard); and (b) $\lambda$ adjusted to 0.06 for the TUHout approach. 


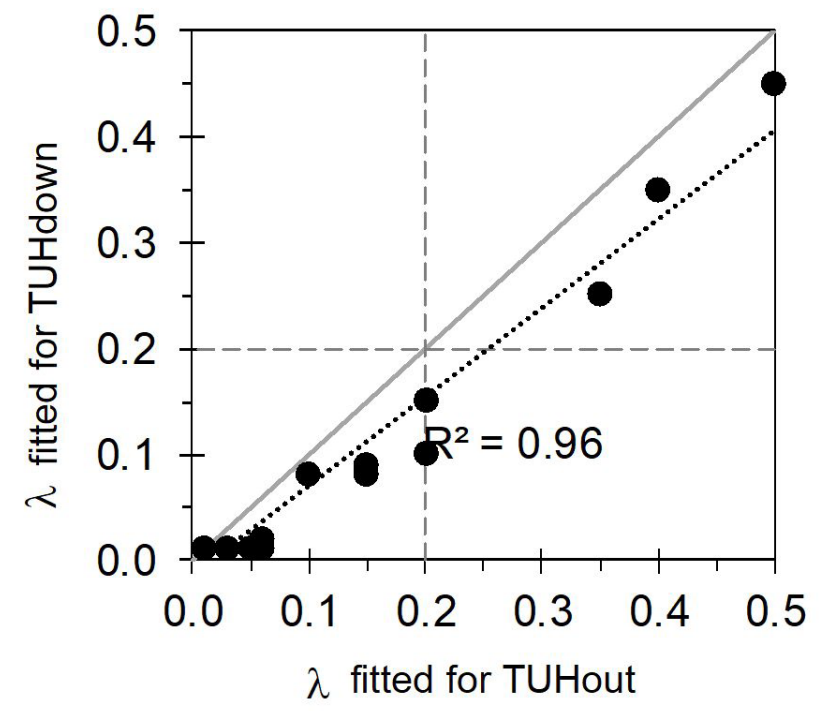

Figure 7. Comparison of $\lambda$ adjusted values between TUHout and TUHdown (grey line is the 1:1 relation and the black dotted line is the linear fitting to the points).

Results in the form of maps such as Figure 6 have advantages over the traditional approach of the NRCS-CN that considers the basin as a concentrate element, since they show the greater contribution of the basin headwaters to the total flow, allowing targeting intervention actions in the river basin.

\section{Hydrographs generation}

Comparing the calculated and observed hydrographs, the relative errors in volumes, runoff peak rates, and time to peak were obtained, in addition to the NS coefficient applied to the hydrographs points (Figures 8 and 9). Figures 10 and 11 at the end of the article show all hydrographs. For both TUHout and TUHdown, when considering the standard $\lambda$ of 0.2 , the relative errors of the three variables were considered high, almost all of them underestimated. In other words, considering this default value of the initial abstraction rate, it was obtained a strong underestimation of the runoff volumes and the runoff peak, as well as the anticipation of the time to peak.

Without calibration of $\lambda$, for the TUHout method, the absolute value of the relative error was greater than $70 \%$ for the volume, runoff peak and time to peak, respectively in $67 \%, 71 \%$ and $33 \%$ of the events. Considering the adjusted $\lambda$, the errors were greatly reduced, and the proportion of events with the relative error greater than $70 \%$ in module dropped to $0 \%, 4 \%$, and $4 \%$, respectively, regarding volume, runoff peak and time to peak. Similar behavior was obtained for TUHdown approach, but with errors slightly lower than those obtained for TUHout.

The comparison between observed and calculated hydrographs shown in Figures 10 and 11 corroborates the fact that the calibration of $\lambda$ allowed to better reproduce the intensity of the observed runoff. For example, in the event 15, 03/11/1980,
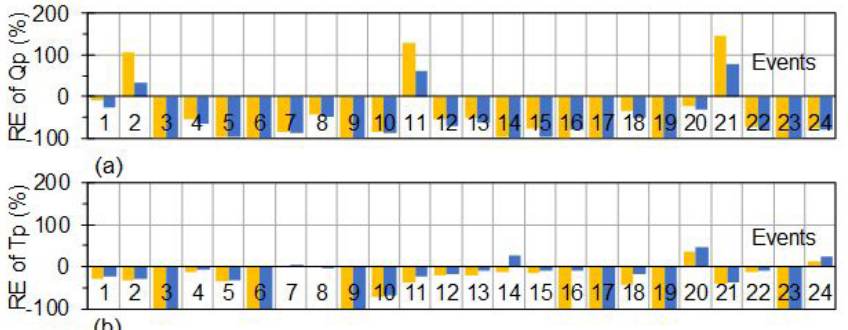

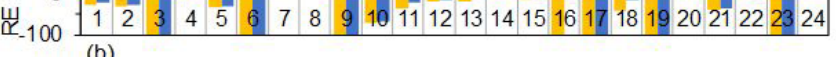

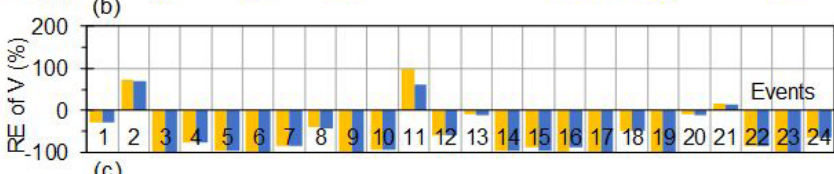

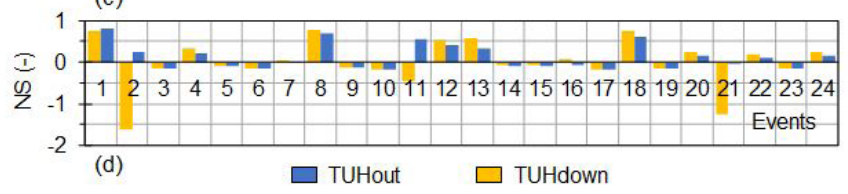

Figure 8. Relative errors (RE) of runoff peak (Qp; a), time to peak (Tp, b), and runoff volume $(\mathrm{V}, \mathrm{c})$, in addition to the NS coefficient (d), considering the standard $\lambda$ of 0.2 for TUHout and TUHdown approaches, covering the 24 simulated events.

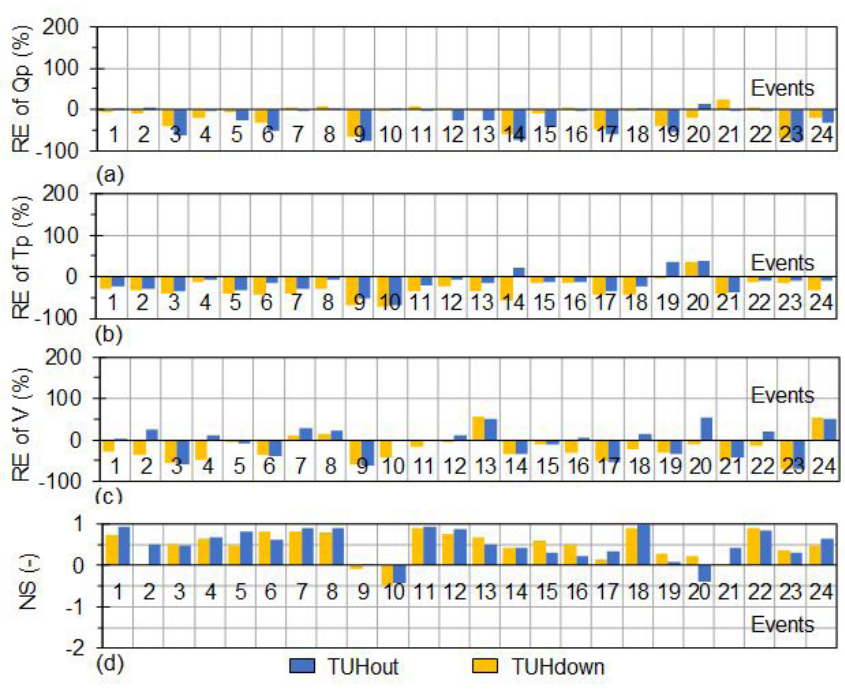

Figure 9. Relative errors (RE) of runoff peak (Qp; a), time to peak (Tp, b) and runoff volume $(\mathrm{V}, \mathrm{c})$, in addition to the NS coefficient (d), considering the adjusted $\lambda$ to TUHout and TUHdown approaches, covering the 24 simulated events.

there was a very good agreement (ER less than 10\% for V and Qp, and $17 \%$ for $\mathrm{Tp}$ ) between observed and calculated runoff by the TUHout approach with the adjusted $\lambda(0.01)$, while the standard $\lambda$ resulted in a negligible pattern in relation to the observed values.

The trend of underestimation of the volumes was higher in the TUHout approach (83\% of the events) than in the TUHdown, who presented a balance between underestimation and overestimation, with $50 \%$ of events in each. In this criterion, the TUHdown method showed to be superior to TUHout. Regarding runoff peak error, both approaches shown to be equivalent, 
predominating the underestimation error, with half of the events with RE less than $20 \%$. When considering the error at the time to peak, again the TUHdown method showed better performance, with $42 \%$ of the events with RE below $20 \%$, while this percentage was $25 \%$ for the TUHout method.
The anticipation of the time to peak was systematically observed in both methodologies, with only one event with a delay error in time to peak in the variant TUHout and three events in the variant TUHdown. In the event of 12/08/1979 (event 10), the simulation with the TUHdown method stood out: RE was
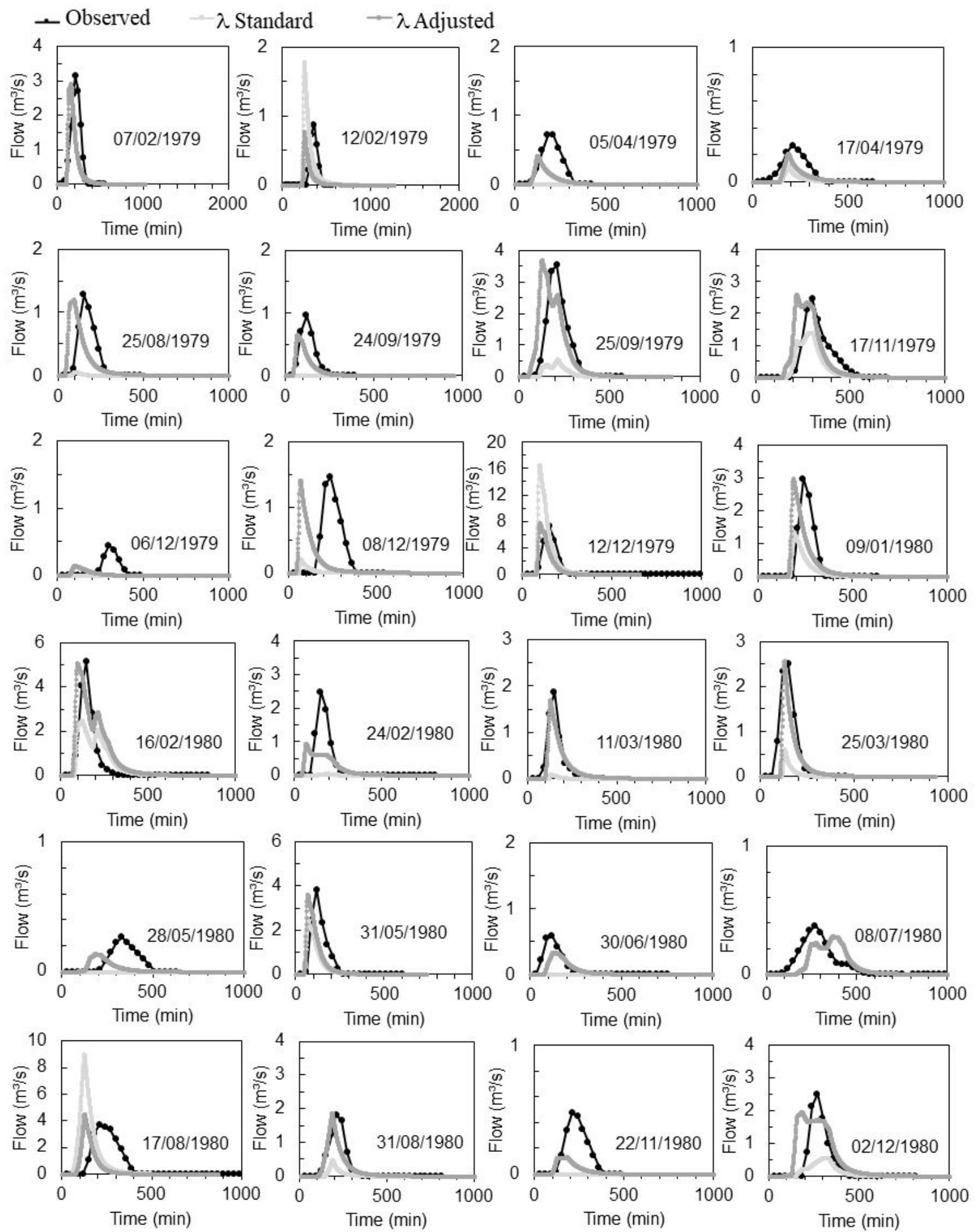

Figure 10. Comparison between observed and calculated hydrographs with the NRCS-CN-TUHout approach considering $\lambda$ standard and $\lambda$ adjusted for all 24 simulated events. 
less than $1 \%$ for $\mathrm{V}$ and $\mathrm{Qp}$ but with the time to peak anticipation around $70 \%$.

Important to mention that Tucci (2003) and Diaz and Tucci (1987) indicated the need to adjust the TUH formulation to better represent the time to peak in Brazilian urban basins. Such a limitation of the original TUH method for Brazilian conditions explains the difficulty in simulating the time to peak runoff with the pixel approach.

Using the standard $\lambda$, only $5(4)$ events $(\sim 20 \%)$ resulted in NS $>0.5$ for the simulations with the variant TUHout(TUHdown). When using the $\lambda$ adjusted, around half of the events reached NS $>0.5$ in both approaches TUHout and TUHdown. This metric,

$\rightarrow$ Observed $\rightarrow \lambda$ Standard $\rightarrow \lambda$ Adjusted
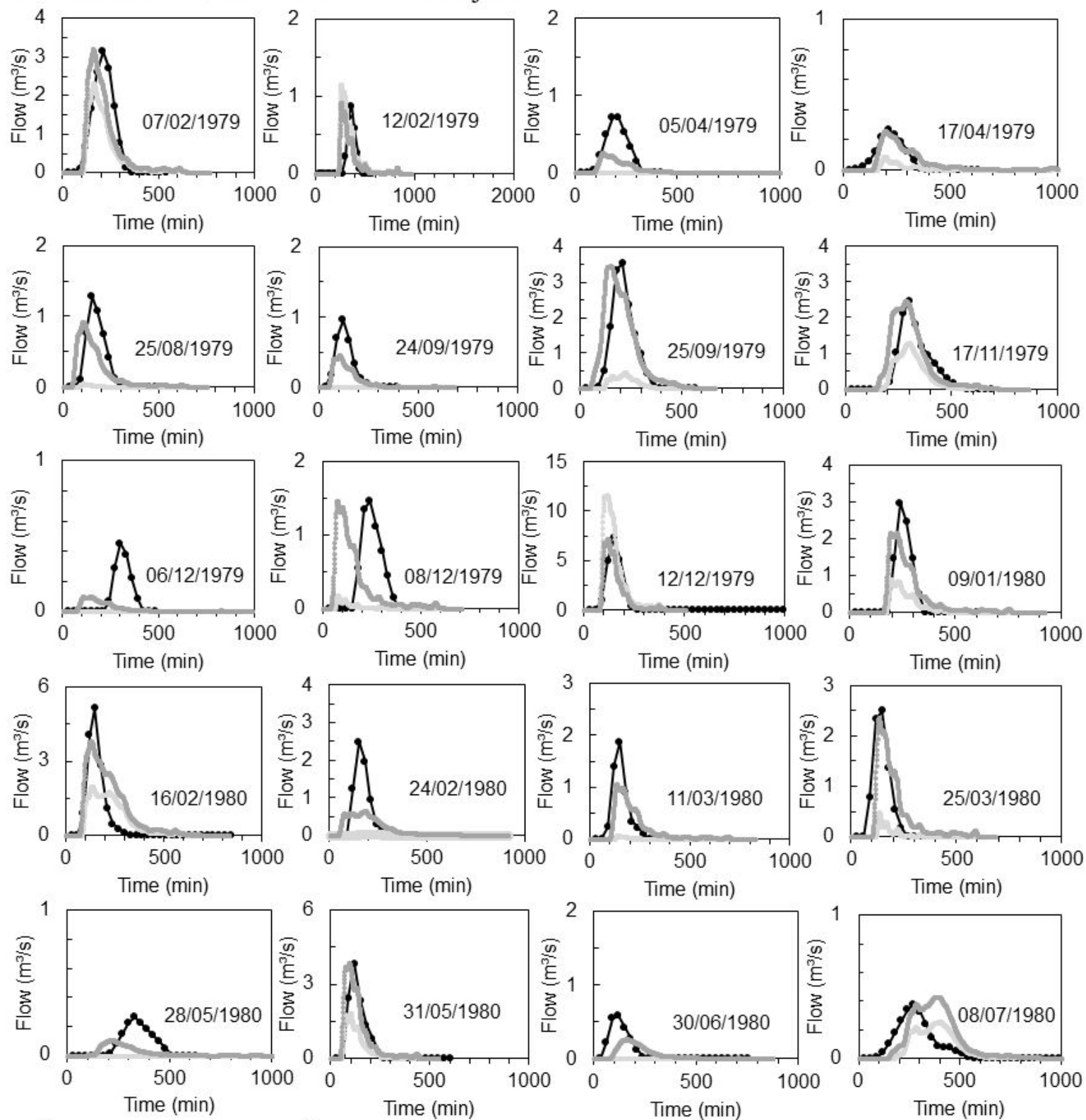

Time (min)
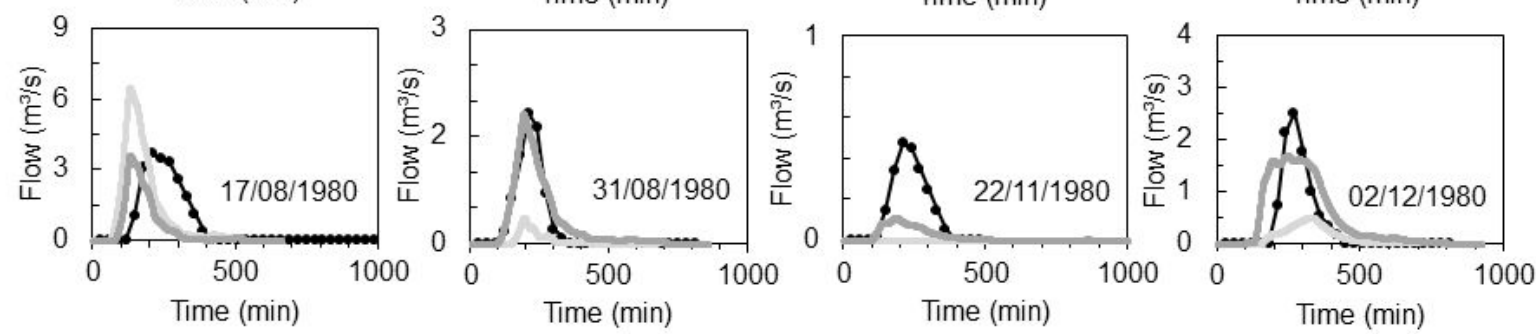

Figure 11. Comparison between observed and calculated hydrographs with the NRCS-CN-TUHdown approach considering $\lambda$ standard and $\lambda$ adjusted for all 24 simulated events. 


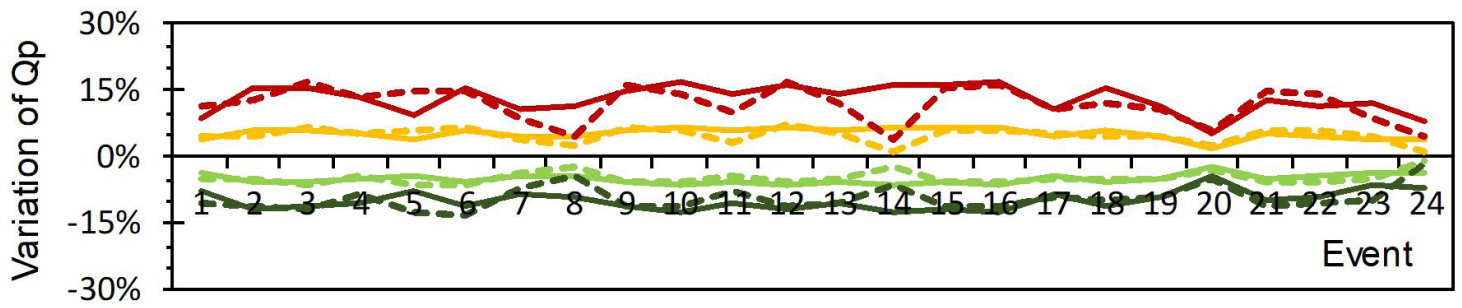

a)
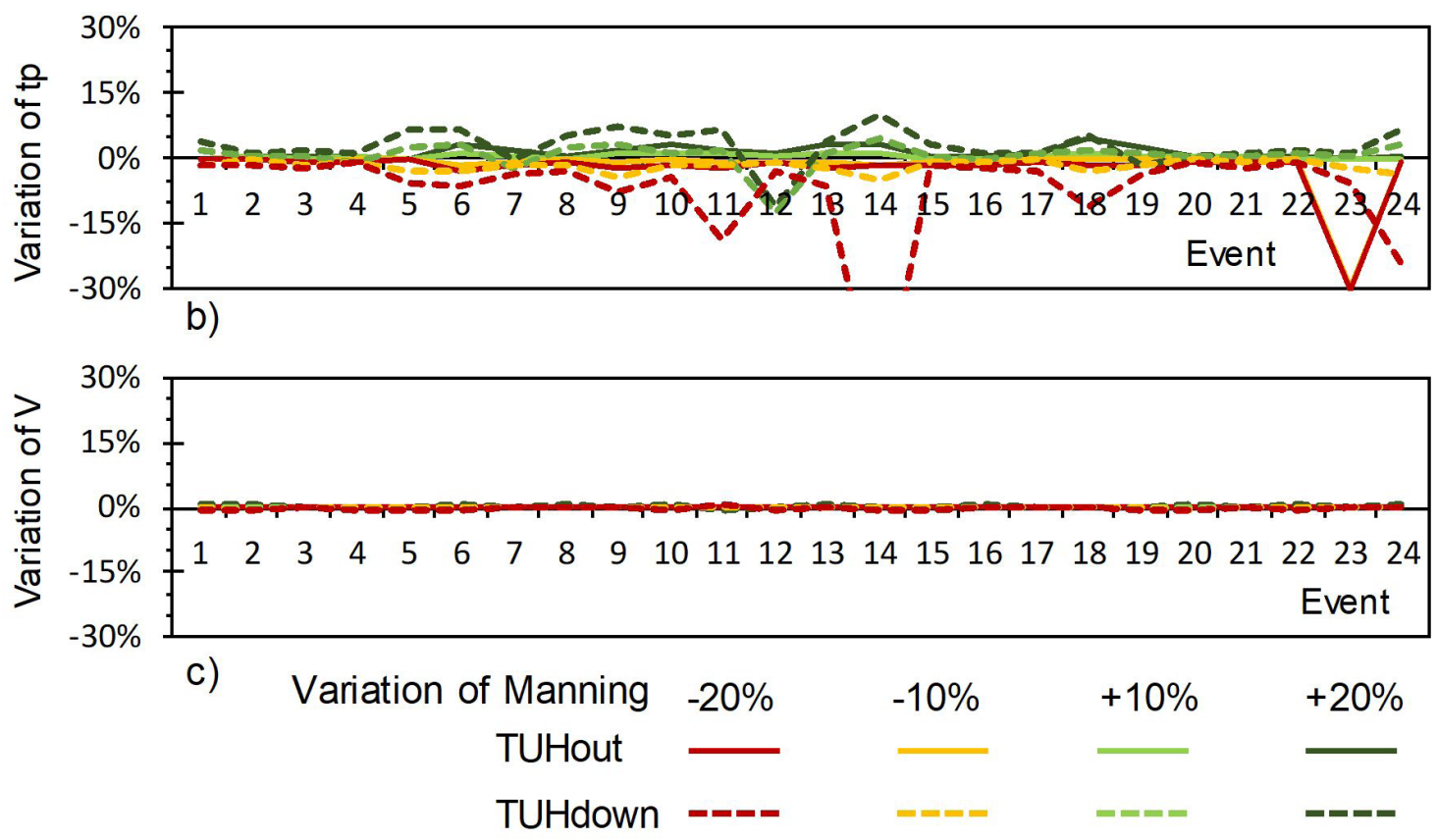

Figure 12. Variation of Qp (a), Tp (b) and volume (c) in function of $-20 \%,-10 \%,+10 \%$ and $+20 \%$ variations on Manning coefficient, for the variants TUHout and TUHdown of the proposed method, covering all the 24 simulated events (note: in ' $b$ ', the variation of Tp of event 14 is $61 \%$, but the vertical scale was kept limited to $30 \%$ in to better detail the remaining results and relative comparison with parts 'a' and 'c').

therefore, also highlights how the adjustment of $\lambda$ was needed to improve the performance of the simulation, in addition to highlighting how the default $\lambda$, in the present study, resulted in simulated discharges with lower performance than considering the average discharge in each event.

Eight additional simulations were performed for each event, varying the adopted Manning coefficient by $+10 \%,+20 \%$, $-10 \%$, and $-20 \%$ in the variants of the method TUHout and TUHdown (Figure 12). This coefficient influences the travel times of the flow, and within the uncertainties in its determination should be included the errors in the DEM, in the land use map, and in the equation of the flow travel time. The results showed clear patterns as follows: i) reductions (increases) in Manning lead to an increase (decrease) in Qp, and that the variations of Manning of $20 \%$ resulted in variations of Qp about 5 to $10 \%$; (ii) reduction(increase) in Manning results in a much lower decrease (increase) of $\mathrm{Tp}$ (with the exception of 4 events); (iii) the variation of the Manning resulted in differences negligible (less than 1\%) in the runoff volume; iv) the variant TUHdown presented results more differentiated between events than the variant TUHout.
In summary: lowest roughness leads to faster flow and increases the runoff peak, but with almost no effect on the total volume.

\section{CONCLUSIONS}

The Hidropixel methodology presented in this paper uses typically available data in ungagged basins such as DEM and satellite imagery to transform the NRCS-CN-TUH methods to operate in a distributed-way per pixel. The results showed good potential to be applied to hydrologic modeling of rainy events in small watersheds without increasing significantly the work required.

Slightly better results were achieved in the variant TUHdown than on TUHout. An explanation may be the fact that, considering the travel time of the pixel to its subsequent downstream pixel as the concentration-time concept for TUHdown application favors the simulation of the runoff attenuation along the basin, in opposition to considering the flow travel time of each pixel up to the basin outlet as adopted by the TUHout approach.

However, both methods underestimated the time to peak indicating a shortcoming of the Hidropixel method to simulate 
the flow timing in this catchment. Limitations and uncertainties of the SRTM30-DEM can contribute to it, by not representing the flow paths and slopes adequately, however, should be noted that authors such as Diaz and Tucci (1987) and Tucci (2003) that derived the TUH parameters already indicated inadequacies of the original TUH methodology for Brazilian catchments, that was the basis for this distributed method. Future studies can be conducted to evaluate the improvements in the rainfall-runoff representation originated from more detailed topographic data, such as from detailed field surveys or airborne laser scanning (LiDAR - Light Detection And Ranging). In addition, the formulation used to estimate the flow travel time was empirically derived from American conditions and may not represent the real conditions of the study area. For example, although the urbanization decreases travel time in the network and increases the runoff peaks, it can happen otherwise in regions with poor drainage that cause floods and ponding (USDA, 1986), as in Brazilian cities.

Difficulties in reproducing the observed flow regime in this study may also be associated to the uncertainties in the observed rainfall and runoff data, rainfall spatial distribution, estimated AMC and also in the graphical separation between surface and base flows as discussed through the paper. Also, relative small events were simulated, while the NRCS-CN formulation was originally proposed for higher return periods.

The calibration of the initial loss rate $(\lambda)$ proposed in the original NRCS-CN method became necessary to avoid large underestimation of flows. In most of the events, $\lambda$ was adopted as 0.01 which is in agreement with the values proposed in recent literature by Ajmal and Kim (2014), Christianson, Hutchinson and Brown (2016), Cazier and Hawkins (1984), and Bosznay (1989).

Some questions remain open for further studies using the distributed simulation approach per pixel proposed in this study, such as the effect of incorporating the spatial rainfall distribution as available from radars or dense rainfall networks, the improvement of topographic representation and flow paths from DEMs of finer spatial resolution and greater precision, and the calibration of the $\mathrm{CN}$ and TUH methods parameters for the Brazilian conditions.

However, the presented results clearly show advantages with its concentrated counterpart approach, as allowing the spatial distribution of excess rainfall, or the characterization of the faster-response parts of the basin. If properly programmed in a GIS environment, these advantages are available with negligible additional effort relative to the concentrated approach. Further research on the methodology and application to other watersheds with different physical characteristics and types of rainfall-runoff response are needed.

\section{ACKNOWLEDGEMENTS}

This study was part of the dissertation of the first author, who attended with a scholarship from Coordenação de Aperfeiçoamento de Pessoal de Nivel Superior - Brasil (CAPES) - Finance Code 001 and integrates a research project financed by CNPq - Edital Universal, coordinated by the second author. The authors also thank $\mathrm{CNPq}$ scholarship granted to the second and third authors, and the data provided by former DEP, especially to the engineers Stanley Amaral and Daniela Bemfica for their contributions as well as the anonymous reviewers.

\section{REFERENCES}

AJMAL, M.; KIM, T. W. Quantifying excess stormwater using SCS-CN-based rainfall runoff models and different curve number determination methods. Journal of Irrigation and Drainage Engineering, v. 141, 2014. http://dx.doi.org/10.1061/(ASCE) IR.1943-4774.0000805.

ALVARES, C.; SANCHEZ, O. J. Estudos hidrológicos da urbanização da bacia do Arroio Diluvio. Porto Alegre: IPH-UFRGS, 1979. Relatório final.

ARNOLD, J. G.; ALLEN, P. M.; MUTTIAH, R.; BERNHARDT, G. Automated base flow separation and recession analysis techniques. Ground Water, v. 33, n. 6, p. 1010-1018, 1995. http:// dx.doi.org/10.1111/j.1745-6584.1995.tb00046.x.

BARTLETT', M. S.; PAROLARI, A. J.; MCDONNELL, J. J.; PORPORATO, A. Beyond the SCS-CN method: a theoretical framework for spatially lumped rainfall-runoff response. Water Resources Research, v. 52, n. 6, p. 4608-4627, 2016. http://dx.doi. org/10.1002/2015WR018439.

BOSZNAY, M. Generalisation of SCS curve number method. Journal of Irrigation and Drainage Engineering, v. 15, n. 1, p. 139-144, 1989. http://dx.doi.org/10.1061/(ASCE)0733-9437(1989)115:1(139).

BUARQUE, D. C.; FAN, F. M.; PAZ, A. R.; COLLISCHONN, W. Comparação de métodos para definir direções de escoamento a partir de modelos digitais de elevação. Revista Brasileira de Recursos Hidricos, v. 14, n. 2, p. 91-103, 2009. http://dx.doi.org/10.21168/ rbrh.v14n2.p91-103.

BURIN, C. W. O caso da canalização do arroio Dilívio em Porto Alegre: ambiente projetado $\times$ ambiente construído. 2008. 161 f. Dissertação (Mestrado em Arquitetura) - Universidade Federal do Rio Grande do Sul, Porto Alegre, 2008.

CANDELA, A.; BRIGANDI, G.; ARONICA, G. T. Estimation of synthetic flood design hydrographs using a distributed rainfallrunoff model coupled with a copula-based single storm rainfall generator. Natural Hazards and Earth System Sciences, v. 14, n. 7, p. 1819-1833, 2014. http://dx.doi.org/10.5194/nhess-14-1819-2014.

CANHOLI, A. P. Drenagem urbana e controle de enchentes. São Paulo: Oficina de Texto, 2005. 384 p.

CAZIER, D. J.; HAWKINS, R. H. Regional application of the curve number method. In: ASCE IRRIGATION AND DRAINAGE DIVISION SPECIALTY CONFERENCE ON WATER MANAGEMENT FOR IRRIGATION AND DRAINAGE, 1994, New York. Proceedings... New York: ASCE, 1984.

CHRISTIANSON, R. D.; HUTCHINSON, S. L.; BROWN, G. O. Curve number estimation accuracy on disturbed and undisturbed soils. Journal of Hydrologic Engineering, v. 21, n. 2, p. 04015059, 2016. http://dx.doi.org/10.1061/(ASCE)HE.1943-5584.0001274.

CUNHA, S. F.; SILVA, F. E. O.; MOTA, T. U.; PINHEIRO, M. C. Avaliação da acurácia dos métodos dos SCS para cálculo da precipitação efetiva e hidrogramas de cheia. Revista Brasileira 
de Recursos Hídricos, v. 20, n. 4, p. 837-848, 2015. http://dx.doi. org/10.21168/rbrh.v20n4.p837-848.

D'ASARO, F. D.; GRILLONE, G.; HAWKINS, R. H.; ASCE, F. Curve number: empirical evaluation and comparison with curve number handbook tables in Sicily. Journal of Hydrologic Engineering, v. 19, n. 12, 2014. http://dx.doi.org/10.1061/(ASCE)HE.19435584.0000997.

DEP - DEPARTAMENTO DE ESGOTOS PLUVIAIS. Caderno de encargos do Departamento de Esgotos Pluviais. Porto Alegre, 2005a.

DEP - DEPARTAMENTO DE ESGOTOS PLUVIAIS. Plano diretor de drenagem urbana: manual de drenagem urbana. Porto Alegre, 2005b. v. 6.

DEP - DEPARTAMENTO DE ESGOTOS PLUVIAIS. Elaboração do plano diretor de drenagem urbana ( $3^{a}$ etapa) e atualização e complementação cadastral, no município de Porto Alegre. Porto Alegre, 2014.

DIAZ, B. P.; TUCCI, C. E. M. Regionalização de hidrogramas unitários de bacias urbanas brasileiras. Revista Brasileira de Engenharia, v. 7, n. 2, p. 19-30, 1987.

EMMANUEL, I.; ANDRIEU, H.; LEBLOIS, E.; JANEY, N.; PAYRASTRE, O. Influence of rainfall spatial variability on rainfall-runoff modelling: Benefit of a simulation approach? Journal of Hydrology, v. 531, n. 2, p. 337-348, 2015. http://dx.doi. org/10.1016/j.jhydrol.2015.04.058.

FAN, F. M.; COLLISCHONN, W.; SORRIBAS, M. V.; PONTES, P. R. M. Sobre o início da rede de drenagem definida a partir dos modelos digitais de elevação. Revista Brasileira de Recursos Hídricos, v. 18, n. 3, p. 241-257, 2013. http://dx.doi.org/10.21168/rbrh. v18n3.p241-257.

FARES, A.; AWAL, R.; MICHAUD, J.; CHU, P.-S.; FARES, S.; KODAMA, K.; ROSENER, M. Rainfall-runoff modeling in a flashy tropical watershed using the distributed HL-RDHM model. Journal of Hydrology, v. 519, p. 3436-3447, 2014. http://dx.doi. org/10.1016/j.jhydrol.2014.09.042.

FAVARETTO, J. R. Emprego da técnica de Krigagem para espacialização das precipitações intensas ocorridas em Porto Alegre - RS. 2014. $90 \mathrm{f}$. Trabalho de Conclusão de Curso (Graduação em Engenharia Civil) - Universidade Federal de Santa Maria, Santa Maria, 2014.

FENSTERSEIFER, C.; ALLASIA, D.; FAVARETTO, J.; BASSO, R.; TASSI, R.; SILVEIRA, A. L. Investigation of urban-induced rainfall in Porto Alegre, Brazil, using TRMM satellite rainfall estimation. In: CLIMATE AND LAND SURFACE CHANGES IN HYDROLOGY: H01, IAHS-IAPSO-IASPEI ASSEMBLY, 2013, Gothenburg, Sweden. Proceedings... London: International Association of Hydrological Sciences, 2013. (IAHS Publ., 359).

GRIMALDI, E. S.; PETROSELLI, A.; NARDI, F. A parsimonious geomorphological unit hydrograph for rainfall-runoff modelling in small ungauged basins. Hydrological Sciences Journal, v. 57, n. 1, p. 73-83, 2012. http://dx.doi.org/10.1080/02626667.2011.636045.
HASENACK, H.; WEBER, E.; MARCUZZO, S. (Ed.). Diagnóstico ambiental de Porto Alegre: geologia, solos, drenagem, vegetação e ocupação. Porto Alegre: Secretaria Municipal do Meio Ambiente, 2008. 84 p.

JENA, S. K.; TIWARI, K. N.; PANDEY, A.; MISHRA, S. K. RS and geographical information system: based evaluation of distributed and composite curve number techniques. Journal of Hydrologic Engineering, v. 17, n. 11, p. 1278-1286, 2012. http:// dx.doi.org/10.1061/(ASCE)HE.1943-5584.0000651.

LAUTHARTE, S. L. Verificação do modelo de hidrograma unitário da SCS para sub-bacias hidrográficas de Porto Alegre. 2015. Trabalho de Conclusão de Curso (Graduação em Engenharia Civil) - Universidade Federal de Santa Maria, Santa Maria, 2015.

LOBLIGEOIS, F; ANDRÉASSIAN, V.; PERRIN, C.; TABARY, P.; LOUMAGNE, C. When does higher spatial resolution rainfall information improve streamflow simulation? An evaluation using 3620 flood events. Hydrology and Earth System Sciences, v. 18, n. 2, p. 575-594, 2014. http://dx.doi.org/10.5194/hess-18-575-2014.

MAJIDI, A.; MORADI, M.; VAGHARFADRD, H.; PURJENAIE, A. Evaluation of Synthetic Unit Hydrograph (SCS) and rational methods in peak flow estimation. Case study: Khoshehaye Zarrin Watershed, Iran. International Journal of Hydraulic Engineering, v. 1, n. 5, p. 43-47, 2012. http://dx.doi.org/10.5923/j.ijhe.20120105.03.

MEJIA, A. I.; MOGLEN, G. E. Impact of the spatial distribution of imperviousness on the hydrologic response of an urbanizing basin. Hydrological Processes, v. 24, n. 23, p. 3359-3373, 2010. http:// dx.doi.org/10.1002/hyp.7755.

MISHRA, S. K.; JAIN, M. K.; SURESH BABU, P.; VENUGOPAL, K.; KALIAPPAN, S. Comparison of AMC-dependent CNconversion Formulae. Water Resources Management, v. 22, n. 10, p. 1409-1420, 2008. http://dx.doi.org/10.1007/s11269-007-9233-5.

MOTTA JUNIOR, J. C.; TUCCI, C. E. M. Simulation of the urbanization effect in flow. Hydrological Sciences Journal, v. 29, n. 2, p. 131-147, 1984. http://dx.doi.org/10.1080/02626668409490930.

NASH, J. E.; SUTCLIFFE, J. V. River flow forecasting through conceptual models part I: a discussion of principles. Journal of Hydrology, v. 10, n. 3, p. 282-290, 1970. http://dx.doi.org/10.1016/00221694(70)90255-6.

OGDEN, F. L.; HAWIINS, R. P.; WALTER, M. T.; GOODRICH, D. C. Comment on "Beyond the SCS-CN method: a theoretical framework for spatially lumped rainfall-runoff response" by M. S. Bartlett et al. Water Resources Research, v. 53, n. 7, p. 6345-6350, 2017. http://dx.doi.org/10.1002/2016WR020176.

PAZ, A. R.; COLLISCHONN, W. River reach length and slope estimates for largescale hydrological models based on a relatively high-resolution digital elevation model. Journal of Hydrology, v. 343, n. 3-4, p. 127-139, 2007. http://dx.doi.org/10.1016/j. jhydrol.2007.06.006.

PAZ, A. R.; COLLISCHONN, W.; SILVEIRA, A. L. L. Improvements in large scale drainage networks derived from digital elevation 
models. Water Resources Research, v. 42, n. 8, 2006. http://dx.doi. org/10.1029/2005WR004544.

PEREIRA, M. A. F.; CAMPO, G. F. N.; KOBIYAMA, M.; CASTRO, N. M. R. Regionalização com geometria hidráulica e fractal: estudo de caso com hidrograma unitário instantâneo geomorfológico. Revista Brasileira de Recursos Hídricos, v. 21, n. 2, p. 347-359, 2016. http://dx.doi.org/10.21168/rbrh.v21n2.p347-359.

RUTKOWSKA, A.; KOHNOVÁ, S.; BANASIK, K.; SZOLGAY, J.; KARABOVÁ, B. Probabilistic properties of a curve number: a case study for small polish and slovak carpthian basins. Journal of Mountain Science, v. 12, n. 3, p. 533-548, 2015. http://dx.doi. org/10.1007/s11629-014-3123-0.

SARAVANAN, E.; MANJULA, R. Geomorphology based semidistributed approach for modeling rainfall-runoff modeling using GIS. Aquatic Procedia, v. 4, p. 908-916, 2015. http://dx.doi. org/10.1016/j.aqpro.2015.02.114.

SARTORI, A.; LOMBARDI NETO, F. L.; GENOVEZ, A. M. Classificação hidrológica de solos brasileiros para a estimativa da chuva excedente com método do serviço de conservação do solo dos Estados Unidos parte 1: classificação. Revista Brasileira de Recursos Hidricos, v. 10, n. 4, p. 5-18, 2005. http://dx.doi.org/10.21168/ rbrh.v10n4.p5-18.

SCS - SOIL CONSERVATION SERVICE. Hydrology. In: U.S. DEPARTMENT OF AGRICULTURE - USDA. National Engineering Handbook. Washington: USDA, 1972. p. 101-1023.

SILVEIRA, A. L. L. Provável efeito urbano nas relações IDF das chuvas de Porto Alegre. Revista Brasileira de Recursos Hídricos, v. 2, n. 2, p. 93-107, 1997. http://dx.doi.org/10.21168/rbrh.v2n2.p93-107.

SILVEIRA, A. L. L. Impactos hidrológicos da urbanização em Porto Alegre. In: TUCCI, C. E. M.; MARQUES, D. M. Avaliação e controle da drenagem urbana. Porto Alegre: UFRGS, 2000. p. 153-163.

SILVEIRA, A. L. L.; DESBORDES, M. Modelo hidrológico distribuído urbano com poucos parâmetros. Revista Brasileira de Recursos Hídricos, v. 4, n. 1, p. 35-48, 1999. http://dx.doi. org/10.21168/rbrh.v4n1.p35-48.

SILVEIRA, A.; BEMFICA, D.; GOLDENFUM, J. Análise da aplicabilidade de padrões de chuva de projeto de Porto Alegre. Revista Brasileira de Recursos Hidricos, v. 5, n. 4, p. 5-16, 2000. http:/ / dx.doi.org/10.21168/rbrh.v5n4.p5-16.

SILVEIRA, A.; GERMANO, A.; TUCCI, C. Estimativa dos parâmetros do modelo IPH II para algumas bacias urbanas brasileiras. Revista Brasileira de Recursos Hídricos, v. 3, n. 4, p. 103-120, 1998. http://dx.doi.org/10.21168/rbrh.v3n4.p103-120.

SPRINGER, E. P.; MCGURK, B. J.; HAWKINS, R. H.; COLTHARP, G. B. Curve numbers from watershed data. In: WATERSHED MANAGEMENT SYMPOSIUM, 1980, Boise, Idaho. Proceedings... New York: ASCE, 1980. p. 938-950.

TUCCI, C. E. M. (Ed.). Hidrologia ciências e aplicação. Porto Alegre: UFRGS-ABRH, 1993.943 p.
TUCCI, C. E. M. Parâmetros do Hidrograma Unitário para bacias urbanas brasileiras. Revista Brasileira de Recursos Hídricos, v. 8, n. 2, p. 195-199, 2003. http://dx.doi.org/10.21168/rbrh.v8n2.p195-199.

TUCCI, C. E. M.; VILLANUEVA, A. O. N.; CRUZ, M. A. S. Banco de eventos de cheias de bacias urbanas brasileiras. Porto Alegre: UFRGS, 1998. Available from: <www.iph.ufrgs.br>. Access on: 19 june 2018.

TUCCI, C. E. M.; VILLANUEVA, A.; CRUZ, M. A. S. Banco de eventos de cheias de bacias urbanas brasileiras. In: TUCCI, C. E. M.; MARQUES, D. M. L. M. Avaliação e controle da drenagem urbana. Porto Alegre: UFRGS, 2000.

USDA - UNITED STATES DEPARTMENT OF AGRICULTURE. NRCS - Natural Resources Conservation Service. CED Conservation Engineering Division. Technical Release 55 (TR-55): urban hydrology for small watersheds. 2nd ed. Washington, 1986.

USDA - UNITED STATES DEPARTMENT OF AGRICULTURE. NRCS - Natural Resources Conservation Service. NEH: National Engineering Handbook. Part 630: hydrology. Washington, 2007. chap. 10 .

VILLANUEVA, A.; PICCILLI, D. Custo da incerteza na macrodrenagem urbana I: determinação dos parâmetros mais sensíveis na modelagem de macrodrenagem urbana. Revista Brasileira de Recursos Hidricos, v. 12, n. 1, p. 65-77, 2007. http:// dx.doi.org/10.21168/rbrh.v12n1.p65-77.

WHITE, K. E.; SLOTO, R. A. Base flow frequency characteristics of selected Pennsylvanian streams. Reston: United States Geological Survey, 1990. 67 p. Water Resources Investigation Report 90-4160. http://dx.doi.org/10.3133/wri904160.

ZHANG, D.; QUAN, J.; WANG, F.; HE, X. Flash flood simulation using geomorphic unit bydrograph method: case study of headwater catchment of Xiapu River Basin, China. New York: CUNY Academic Works, 2014. Available from: < https://academicworks. cuny.edu/cc_conf_hic/132>. Access on: 19 june 2018.

\section{Authors contributions}

Fagner França da Costa: Contributed to literature review, study design, methodology development and application, results discussion and paper writing.

Adriano Rolim da Paz: Contributed to literature review, study design, methodology development and application, results discussion and paper writing.

Daniel Gustavo Allasia Piccilli: Contributed to study design, literature review, methodology application, results discussion and paper writing. 